\title{
Lipid peroxidation induced by Clinostomum detruncatum in muscle of the freshwater fish Rhamdia quelen
}

\author{
A. R. R. Belló ${ }^{1}$, E. Fortes ${ }^{1}$, A. Belló-Klein ${ }^{2, *}$, A. A. Belló ${ }^{2}$, S. F. Llesuy ${ }^{2}$, R. B. Robaldo ${ }^{3}$, A. Bianchini ${ }^{3}$ \\ ${ }^{1}$ Departamento de Parasitologia and ${ }^{2}$ Departamento de Fisiologia, Universidade Federal do Rio Grande do Sul, \\ Rua Sarmento Leite, 500, 90050-170, Porto Alegre-RS, Brazil \\ ${ }^{3}$ Departamento de Ciências Fisiológicas, Fundação Universidade Federal do Rio Grande, R. Eng. Alfredo Huch, 475, 96201-900, \\ Rio Grande-RS, Brazil
}

\begin{abstract}
The effect of Clinostomum detruncatum metacercaria infection on the activities of the antioxidant enzymes superoxide dismutase and catalase in muscle of the freshwater fish Rhamdia quelen was analyzed. Tert-butyl hydroperoxide-initiated chemiluminescence, a measure of lipid peroxidation, was also investigated. Enzyme activities were similar in infected and uninfected fishes. However, the chemiluminescence was almost 2-fold higher in muscle of infected fishes than in muscle of uninfected ones. These results indicate that parasite infection induces oxidative stress and a higher level of membrane damage in the fish muscle due to an imbalance between pro-oxidants and non-enzymatic antioxidants. Our results suggest that fish response to parasite infection could involve, as in other vertebrates, reactive oxygen intermediates.
\end{abstract}

KEY WORDS: Parasite $\cdot$ Oxidative stress $\cdot$ Lipid peroxidation $\cdot$ Fish

Resale or republication not permitted without written consent of the publisher

The instability of active oxygen species and the effects of these species on cells and tissues lead fish, like other vertebrates, to present several enzymatic and non-enzymatic defense systems with antioxidant capacities (Del Maestro 1980, Sies \& Murphy 1991, Sies 1993, Wilhelm Filho 1996). Under normal conditions, there is an equilibrium between pro-oxidant production and antioxidant defenses. An imbalance in favour of pro-oxidants characterizes the oxidative stress condition (Machlin \& Bendich 1987, Sies 1993). This situation could induce higher lipid peroxidation ratios in tissues and cell damage (Southorn \& Powis 1988).

In aquatic animals, several conditions are reported to induce oxidative stress. For example, it may result as a response to several xenobiotics and hormonal changes

*Corresponding author. E-mail: belklein@vortex.ufrgs.br
(Videla et al. 1995, Bainy et al. 1996) or when animals are exposed to normoxia after having repeatedly experienced prolonged periods of anoxia or ischaemia (Storey 1996). Data reporting changes in oxidative stress associated with parasite infection in these animals are extremely scarce (Dykens 1984, Dikkeboom et al. 1988, Nabih \& El-Ansary 1993, Neves et al. 2000). Furthermore, as far as we know, there are no records for fishes.

Considering the above facts and that the freshwater fish Rhamdia quelen is an intermediary host of the trematode Clinostomum sp. (Fortes \& Hoffmann 1980), the aim of this work was to analyze the possible oxidative stress and lipid peroxidation induced by Clinostomum detruncatum parasitism in the muscle of $R$. quelen.

Material and methods. Freshwater fish Rhamdia quelen were collected at Sarandi rivulet near Chui city (Southern Brazil). They were measured (20.5 to $36.0 \mathrm{~cm}$ ), weighed (148 to $508 \mathrm{~g}$ ), and sacrificed. Muscle samples from 6 uninfected and 6 Clinostomum detruncatum infected fishes were obtained near the pectoral fins. In infected fishes, muscle samples were collected near the parasite cyst without including it. All samples were maintained in dry ice for transportation. In the laboratory, they were frozen $\left(-70^{\circ} \mathrm{C}\right)$. For analysis, the muscle sample $(1 \mathrm{~g})$ was defrosted and homogenized in $5 \mathrm{ml}$ of an ice-cold buffer solution (140 mM $\mathrm{KCl}, 20 \mathrm{mM}$ phosphates). Homogenization was performed in an Ultra-turrax, for $30 \mathrm{~s}$ at 0 to $4^{\circ} \mathrm{C}$. The homogenate was centrifuged $(1000 \times g)$ for $10 \mathrm{~min}$ (Llesuy et al. 1985). The supernatant was then collected and separated into aliquots for protein, chemiluminescence, and superoxide dismutase (SOD; EC 1.15.1.1) and catalase (CAT; EC 1.11.1.6) activity determinations. 
Protein concentration of the homogenate was determined following the method described by Lowry et al. (1951) and employing bovine albumin $\left(1 \mathrm{mg} \mathrm{ml}^{-1}\right)$ as standard. All measurements were performed in duplicate.

Enzyme activities in the homogenate were performed according to the method described by Halliwell \& Gutteridge (1989). Total SOD (CuZnSOD + MnSOD) activity was determined as the inhibition rate of autocatalytic adenocrome generation at $480 \mathrm{~nm}$ in a reaction medium containing $1 \mathrm{mM}$ epinephrine and $50 \mathrm{mM}$ glycine- $\mathrm{NaOH}$ (pH 10.5). Enzyme activity was expressed in units per mg protein. Catalase activity was measured as the decrease in absorption at $240 \mathrm{~nm}$ in a reaction medium containing $50 \mathrm{mM}$ phosphate buffer ( $\mathrm{pH}$ 7.2) and $10 \mathrm{mM} \mathrm{H}_{2} \mathrm{O}_{2}$. Enzyme activity was expressed in pmol catalase per mg protein (Chance 1954).

Chemiluminescence, an indicator of lipid peroxidation, was measured employing the hydroperoxideinitiated chemiluminescence assay described by Boveris et al. (1985) and Gonzalez-Flecha et al. (1991). In brief, the homogenate was defrosted and $500 \mu$ l were diluted in a buffer solution $(120 \mathrm{mM} \mathrm{KCl}, 40 \mathrm{mM}$ phosphates; $\mathrm{pH} 7.4$ ) to give a final concentration of $1 \mathrm{mg}$ protein $\mathrm{ml}^{-1}$. The final volume was placed in a glass vial previously kept in darkness, in order to avoid the vial phosphorescence induced by the fluorescent light. Tert-butyrate hydroperoxide (Sigma Co.) was added to the diluted homogenate to give a final concentration of $3 \mathrm{mM}$. Chemiluminescence was measured employing a $\beta$ scintillator (LKB Rack Beta Liquid Scintillation Spectrometer, Bromma, Sweden), for $40 \mathrm{~min}$. All procedures were performed in darkness. Chemiluminescence was calculated considering the initial and maximal emissions, as well as the final volume and the protein concentration of the reaction medium. Chemiluminescence was then expressed in counts per second (cps) per mg protein.

All data are expressed as means \pm SE. Data were subjected to the Student's $t$-test $(\alpha=0.05)$.

In order to identify the parasite infecting Rhamdia quelen, cysts from muscle of infected fish were isolated and opened. The trematodes obtained were maintained in Petri dishes containing ice-cold NaCl 0.65\% for several hours to distend the parasite. Parasite fixation was performed by compressing it between slide and cover glass immersed in Raillet-Henry's solution. The preparation was stained with Langeron's carmine chloride and mounted using Canada balsam.

Results. The parasite infecting the muscles of the freshwater teleost Rhamdia quelen was identified as being a metacercaria of the digenean Clinostomum detruncatum (Fig. 1). During fish capture, it was observed that parasite cysts are always located at the base of fish pectoral and/or caudal fins.
Protein concentration and SOD and CAT activities were similar in muscle homogenates of uninfected and Clinostomum detruncatum infected fishes. However, hydroperoxide-initiated chemiluminescence in the muscle homogenate of infected fish was almost 2-fold higher than that in uninfected ones (Table 1). Typical chemiluminescence kinetics in muscle of infected and uninfected Rhamdia quelen is shown in the Fig. 2.

Discussion. As far as we know, this is the first attempt to demonstrate the effect of parasitism on the oxidative status of fish. Taking into account that parasitism induced higher oxygen and energy consumption in fish (Lemly \& Esch 1984), an increased oxidative metabolism and possibly oxidative stress would be expected in Rhamdia quelen infected by Clinostomum detruncatum.

With respect to the enzymatic antioxidant defenses, SOD activity in muscle of uninfected Rhamdia quelen was similar to that determined in muscle of other teleost fishes (Fitzgerald 1992). Furthermore, when SOD and CAT activities were compared to those measured in muscle of several other marine or freshwater fish species, they agreed with the pattern described for freshwater and marine species. In this case, SOD activity is lower in freshwater species than in marine ones, and the opposite is observed for CAT activity (Wilhelm Filho 1996). Finally, SOD and CAT activities in muscle of $R$. quelen were, as expected, much lower than those registered in several other tissues of freshwater and marine fishes (Wilhelm Filho \& Boveris 1993, Wilhelm Filho et al. 1993, Bainy et al. 1996).

With respect to the effect of parasite infection on SOD and CAT activities, no significant differences were observed between activities measured in muscle

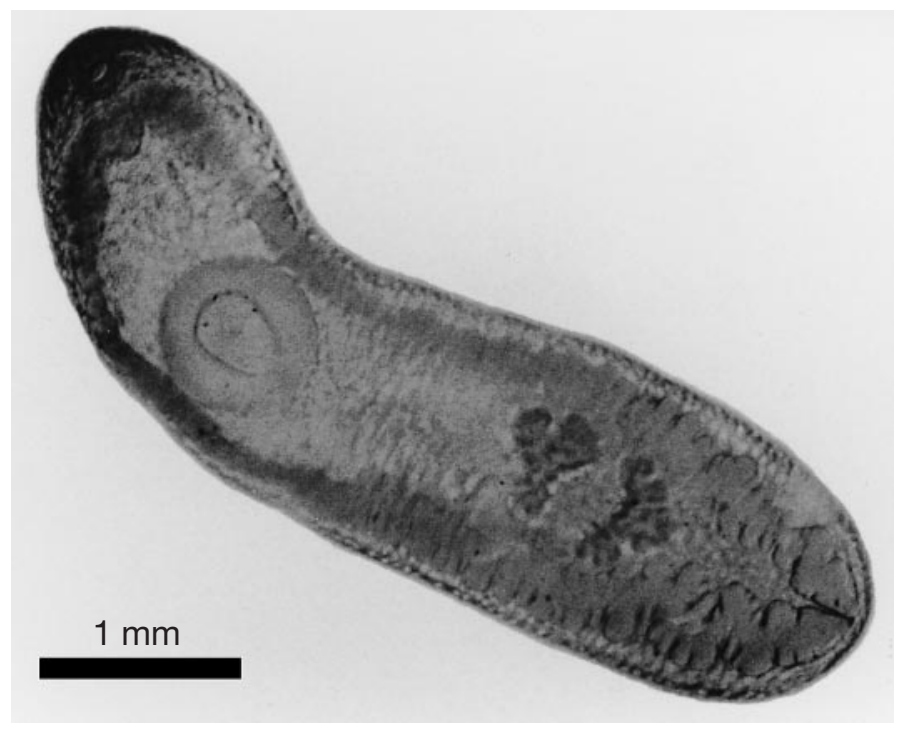

Fig. 1. Metacercaria of Clinostomum detruncatum isolated from muscle of the freshwater teleost Rhamdia quelen 
Table 1. Protein concentration, antioxidant enzyme activities, and Tert-butyl hydroperoxide-initiated chemiluminescence in muscle homogenates of the freshwater teleost Rhamdia quelen infected and uninfected by Clinostomum detruncatum metacercaria. Data are means $\pm \mathrm{SE}(\mathrm{N}=6)$. ${ }^{*}$ Means significantly different for the same parameter $(p<0.05)$

\begin{tabular}{|c|c|c|}
\hline Parameter & Uninfected fish & Infected fish \\
\hline Protein $\left(\mathrm{mg} \mathrm{ml}^{-1}\right)$ & $5.6 \pm 0.33$ & $5.4 \pm 0.19$ \\
\hline $\begin{array}{l}\text { Superoxide dismutase } \\
\text { (U mg }{ }^{-1} \text { protein) }\end{array}$ & $0.64 \pm 0.04$ & $0.75 \pm 0.02$ \\
\hline $\begin{array}{l}\text { Catalase } \\
\quad\left(\text { pmol } \mathrm{mg}^{-1} \text { protein }\right)\end{array}$ & $2.59 \pm 0.18$ & $2.30 \pm 0.30$ \\
\hline $\begin{array}{l}\text { Chemiluminescence } \\
\text { (cps mg } \text { m }^{-1} \text { protein) }\end{array}$ & $15619 \pm 891$ & $29481 \pm 1189^{*}$ \\
\hline
\end{tabular}

homogenates of Rhamdia quelen infected and uninfected by Clinostomum detruncatum metacercaria. This result could indicate that parasitism did not lead to oxidative stress in the fish muscle. However, the chemiluminescence observed in the muscle homogenate of infected fishes was almost 2-fold higher than that measured in uninfected ones. It is important to note that Tert-butyl hydroperoxide-initiated chemiluminescence indicates not only the extent of lipid peroxidation and membrane damage, but also the balance between non-enzymatic antioxidants and pro-oxidants (Halliwell \& Gutteridge 1989, Gonzalez-Flecha et al. 1991). Thus, despite the fact that non-enzymatic antioxidant supply was not analyzed, our results strongly indicate that $C$. detruncatum infection reduces the non-enzymatic antioxidant defenses with respect to pro-oxidant production in the muscle of the freshwater teleost $R$. quelen. This situation leads to oxidative stress and consequently muscle damage via products from lipid peroxidation. As observed in mammals (Senok et al. 1998, Gharib et al. 1999), this increased

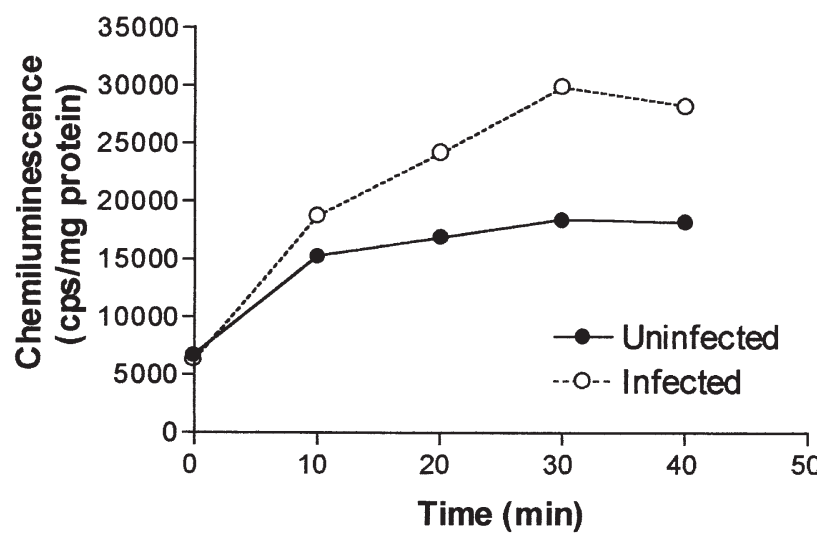

Fig. 2. Typical kinetics of the Tert-butyl hydroperoxide-initiated chemiluminescence in homogenized muscle of the freshwater teleost Rhamdia quelen infected and uninfected by Clinostomum detruncatum metacercaria oxidative stress induced by the fish as an immune response to parasite infection could be taking place in order to induce oxidative damage to parasite membranes.

Regarding the Clinostomum sp. life cycle, our results suggest that there may be a partnership between the parasite and piscivorous birds. Taking into account that the $C$. detruncatum infection takes place at the base of Rhamdia quelen fins and that this infection induces muscle damage via lipid peroxidation products, piscivorous birds could be preying more easily on infected fish. At the same time, the parasite would be employing the bird to conclude its life cycle.

Acknowledgements. We thank Dr Mary Jane Tweedie de Mattos for the parasite identification, Dr Joaber Pereira Jr for valuable suggestions and bibliography, and Tânia Regina Gattelli Fernandes for technical assistance. A.R.R.B. and R.B.R. were recipients of CNPq fellowships. A.B.-K., A.A.B. and A.B. are research fellows of the Brazilian CNPq (National Council for Scientific and Technology Development).

\section{LITERATURE CITED}

Bainy ACD, Saito E, Carvalho PSM, Junqueira VBC (1996) Oxidative stress in gill, erythrocytes, liver and kidney of Nile tilapia (Oreochromis niloticus) from a polluted site. Aquat Toxicol 34:151-162

Boveris A, Llessuy SF, Fraga CG (1985) Increased liver chemiluminescence in tumor-bearing mice. Biochem Pharmacol $1: 131-138$

Chance B (1954) Special methods: catalase. In: Glick D (ed) Methods of biochemical analysis. Interscience, New York, p 408-424

Del Maestro RF (1980) An approach to free radicals in medicine and biology. Acta Physiol Scand 107:153-158

Dikkebom R, van der Knaap WPW, van den Bovenkamp W, Tijnagel JMGH, Bayne CJ (1988) The production of toxic oxygen metabolites by hemocytes of different snail species. Dev Comp Immunol 12:509-520

Dykens JÁ (1984) Enzymatic defences against oxygen toxicity in marine cnidarians containing endosymbiotic algae. Mar Biol 5:291-301

Fortes E, Hoffmann RP (1980) Ocorrência de helmintos parasitas de peixes do estuário do Guaíba, no Estado do Rio Grande do Sul. IV. Trematódeos digenéticos. Arq Fac Vet UFRGS 9:129-132

Fitzgerald JP (1992) Comparative analysis of superoxide dismutase activities in a range of temperate and tropical teleost fish. Comp Biochem Physiol 101B:111-114

Gharib B, Abdallahi OMS, Dessein H, De Reggi M (1999) Development of eosinophil peroxidase activity and concomitant alteration of the antioxidant defenses in the liver of mice infected with Schistosoma mansoni. J Hepatol 30: 594-602

Gonzalez-Flecha B, Llessuy SF, Boveris A (1991) Hydroperoxide-initiated chemiluminescence: an assay for oxidative stress in biopsies of heart, liver and muscle. Free Rad Biol Med 10:93-100

Halliwell B, Gutteridge JMC (1989) Free radicals in biology and medicine, 2nd edn. Clarendon Press, Oxford

Lemly D, Esch MJ (1984) Platelminta. In: de Almeida A (ed) 
Elementos de ictioparasitologia. Fundação Eng Porto, p 158

Llesuy SF, Milei J, Molina H, Boveris A, Milei S (1985) Comparison of lipid peroxidation and myocardial damage induced by adriamycin in mice. Tumori 71:241-249

Lowry OH, Rosenbrough NJ, Farr AL, Randall RJ (1951) Protein measurement with the folin reagent. J Biol Chem 93:265-269

Machlin L, Bendich A (1987) Free radical tissue damage: protective role of antioxidant nutrients. FASEB J 1:441-445

Nabih I, El-Ansary A (1993) Kinetic potentials of certain scavenger enzymes in freshwater snails susceptible and nonsusceptible to Schistosoma infection Cell Mol Biol 39: 449-454

Neves CA, Santos EA, Bainy ACD (2000) Reduced superoxide dismutase activity in Palaemonetes argentinus (Decapoda, Palemonidae) infected by Probopyrus ringueleti (Isopoda, Bopyridae). Dis Aquat Org 39:155-158

Senok AC, Li K, Nelson EAS, Arumanayagam M, Li CK (1998) Flow cytometric assessment of oxidant stress in agefractionated thalassaemic trait erythrocytes and its relationship to in vivo growth of Plasmodium falciparum. Parasitology 116:1-6

Editorial responsibility: Wolfgang Körting,

Hannover, Germany
Sies H (1993) Strategies of antioxidant defense. Eur J Biochem 215:213-219

Sies H, Murphy ME (1991) Role of tocopherols in the protection of biological systems against oxidative damage. J Photochem Photobiol B Biol 8:211-224

Southhorn P, Powis G (1988) Free radicals in medicine. I. Chemical nature and biological reactions. Mayo Clin Proc 63:390-408

Storey KB (1996) Oxidative stress: animal adaptations in nature. Braz J Med Biol Res 29:1715-1733

Videla LA, Fernández V, Carrión Y, Azzalis LA, Bainy ACD, Junqueira VBC (1995) Cellular oxidative stress induced by xenobiotics and hormonal changes. Ciênc Cult 47: 385-394

Wilhelm Filho D (1996) Fish antioxidant defenses - a comparative approach. Braz J Med Biol Res 29:1735-1742

Wilhelm Filho D, Boveris A (1993) Antioxidant defences in marine fish-II. Elasmobranchs. Comp Biochem Physiol 106C:415-418

Wilhelm Filho D, Giulivi C, Boveris A (1993) Antioxidant defences in marine fish-I. Teleosts. Comp Biochem Physiol 106C:409-413

Submitted: February 29, 2000; Accepted: June 5, 2000

Proofs received from author(s): August 13, 2000

\section{Erratum}

\section{A dual infection of infectious salmon anaemia (ISA) virus and a togavirus-like virus in ISA of Atlantic salmon Salmo salar in New Brunswick, Canada}

\section{F. S. B. Kibenge, S. K. Whyte, K. L. Hammell, D. Rainnie, M. T. Kibenge, C. K. Martin}

Dis Aquat Org 42:11-15, 2000

It has been brought to the authors' attention that the 'Materials and methods' section, in the subsection 'RT-PCR', should have the GenBank accession number AF030878 for the togavirus-like virus cDNA clone
M107, and the primer sequences 5'-GTC TGA ACT GGA CTC TTG ACG C-3' (M107F1, sense) and 5'TGC AAG CGA ACC TGT AGA CG-3' (M107R1, antisense) for the togavirus-like virus-specific primer pair. 